\title{
A cross-sectional study of the filarial and Leishmania co-endemicity in two ecologically distinct settings in Mali
}

\author{
Moussa Brema Sangare 1 , Yaya Ibrahim Coulibaly ${ }^{1 *}$, Siaka Yamoussa Coulibaly ${ }^{1}$, Michel Emmanuel Coulibaly ${ }^{1}$, \\ Bourama Traore1, Ilo Dicko', Ibrahim Moussa Sissoko', Sibiry Samake', Sekou Fantamady Traore', \\ Thomas Bruce Nutman², Jesus Gilberto Valenzuela ${ }^{3}$, Ousmane Faye ${ }^{4}$, Shaden Kamhawi ${ }^{3}$, Fabiano Oliveira ${ }^{3}$, \\ Roshanak Tolouei Semnani ${ }^{2}$ and Seydou Doumbia ${ }^{1}$
}

\begin{abstract}
Background: Filariasis and leishmaniasis are two neglected tropical diseases in Mali. Due to distribution and associated clinical features, both diseases are of concern to public health. The goal of this study was to determine the prevalence of co-infection with filarial (Wuchereria bancrofti and Mansonella perstans) and Leishmania major parasites in two ecologically distinct areas of Mali, the Kolokani district (villages of Tieneguebougou and Bougoudiana) in North Sudan Savanna area, and the district of Kolondieba (village of Boundioba) in the South Sudan Savanna area.

Methods: The prevalence of co-infection (filarial and Leishmania) was measured based on (i) Mansonella perstans microfilaremia count and/or filariasis immunochromatographic test (ICT) for Wuchereria bancrofti-specific circulating antigen, and (ii) the prevalence of delayed type hypersensitivity (DTH) responses to Leishmania measured by leishmanin skin test (LST).
\end{abstract}

Results: In this study, a total of 930 volunteers between the age of 18 and 65 were included from the two endemic areas of Kolokani and Kolondieba. In general, in both areas, filarial infection was more prevalent than Leishmania infection with an overall prevalence of 15.27\% (142/930) including 8.7\% (81/930) for Mansonella perstans and 8\% (74/ 930) for Wuchereria bancrofti-specific circulating antigen. The prevalence of Leishmania major infection was 7.7\% (72/ 930) and was significantly higher in Tieneguebougou and Bougoudiana (15.05\%; 64/425) than in Boundioba (2.04\%; 8/ 505) $\left(X^{2}=58.66, P<0.0001\right)$. Among the filarial infected population, nearly $10 \%(14 / 142)$ were also positive for Leishmania with an overall prevalence of co-infection of 1.50\% (14/930) varying from 2.82\% (12/425) in Tieneguebougou and Bougoudiana to $0.39 \%(2 / 505)$ in Boundioba $(P=0.0048)$.

Conclusion: This study established the existence of co-endemicity of filarial and Leishmania infections in specific regions of Mali. Since both filarial and Leishmania infections are vector-borne with mosquitoes and sand flies as respective vectors, an integrated vector control approach should be considered in co-endemic areas. The effect of potential interaction between filarial and Leishmania parasites on the disease outcomes may be further studied.

Keywords: Filariae, Mansonella perstans, Wuchereria bancrofti, Leishmania major, Co-endemicity, Vector-borne diseases, Mali

\footnotetext{
* Correspondence: yicoulibaly@icermali.org

${ }^{1}$ International Center of Excellence in Research, Faculty of Medicine and

Odontostomatology, Point G, Bamako, Mali

Full list of author information is available at the end of the article
} 


\section{Background}

Neglected tropical diseases (NTDs) are among chronic, disabling, and disfiguring diseases that occur most commonly in the setting of extreme poverty, especially among the rural poor and some disadvantaged urban populations having important socioeconomic impact $[1,2]$.

Filarial infections are chronic debilitating infections mostly caused by the mosquito-borne filarial nematodes, Wuchereria bancrofti, Brugia malayi and Brugia timori [1]. Worldwide, more than one billion people are at risk of infection for filariasis and 120 million people in the tropical and subtropical areas of the world are infected with parasites causing lymphatic filariasis (LF) [3]. The majority of those at risk of infection live in South-East Asia and Africa [4]. Wuchereria bancrofti (W. bancrofti) and Mansonella perstans (M. perstans) are the two major filarial infections found in Mali [5]. Before the mass drug administration (MDA), and based on the immunochromatographic card test (ICT), all districts were shown to be endemic for LF with an overall prevalence of $7.07 \%$ (ranging from $1 \%$ in the north to $18.6 \%$ in the south of Mali) [6]. Furthermore, the parasitological and entomological data from previous studies confirmed the districts of Sikasso in the South Sudan Savanna area and Kolokani in the North Sudan Savanna area as two areas of high W. bancrofti transmission [7].

Leishmaniasis is a vector-borne neglected disease transmitted to the host via the bite of Leishmania-infected female phlebotomine sand flies. Depending on the Leishmania species, humans can develop visceral or cutaneous forms of the disease. In the Old World (Africa, Europe and Asia), cutaneous leishmaniasis (CL) is characterized by skin lesions that can develop into unsightly scars, typically on the face and extremities. Lesions can heal spontaneously within several months, persist or relapse as chronic non-healing ulcers, or develop into complicated CL defined as mucosal lesions, nodular lymphangitis, and cutaneous dissemination (in immunocompromised individuals) [8]. Leishmaniasis is prevalent in more than 90 countries with an estimated 1.3 million new cases every year worldwide, and 20,000 to 30,000 deaths annually [9]. Furthermore, CL is the most reported form of this disease in some West African countries including Guinea Bissau [10, 11], Senegal [12, 13], Niger [14], Burkina Faso [15], Mali [16, 17] and Ghana [18, 19]. In Mali, Leishmania major (L. major) is the only species of Leishmania known to cause CL [20, 21] with Phlebotomus duboscqi (P. duboscqi) as the main sand fly vector in the country [21]. In 2009, a leishmanin skin test (LST) survey showed a high positivity rate of LST $(45.4 \%)$ in Kemena and Sougoula, two villages in the central part of Mali [22]. The prevalence of $L$. major infection in $P$. duboscqi sand fly females was $2.7 \%$ in central Mali, confirmed by sequence alignment of a subset of polymerase chain reaction (PCR) products from infected sand flies; this vector is found in areas endemic for LF in Mali [21].
Since both filarial and Leishmania infections are vectorborne diseases with mosquitoes and sand flies as respective vectors, understanding the prevalence of their concurrent distribution may guide the disease control programme for evidence based integrated vector control approaches in coendemic areas. It also contributes to an understanding of the significance of potential interaction between filarial and Leishmania parasites on the disease outcomes and may be further studied.

This study aimed to assess the prevalence of coendemicity between the filarial parasites ( $W$. bancrofti and $M$. perstans) and L. major parasite in Mali. To investigate the overlap between the two infections, we conducted a cross-sectional study in two ecologically distinct regions: in the Kolokani district (North Sudan Savanna area) and in the district of Kolondieba (South Sudan Savanna area).

\section{Methods \\ Study sites}

The study was conducted in the villages of Tieneguebougou and Bougoudiana in the Kolokani district (North Sudan Savanna area) and Boundioba in the district of Kolondieba (South Sudan Savanna area) (Fig. 1). The choice of these villages was based on historical data from previous studies of filariasis [7] where the prevalence of W. bancrofti infection was shown to be $48.3 \%$, and coinfection with $M$. perstans to be $40.7 \%$ [23]. Notably, all regions in Mali are endemic for LF [6]. Cutaneous leishmaniasis was reported in the neighboring districts of Kolokani and Baroueli [22] but not in the south areas of Kolondieba.

A complete census, including the name, age, sex, and profession of all inhabitants, was performed in the study villages prior to the parasitological assessment. The population size of the villages varied from 1521 inhabitants in Tieneguebougou and Bougoudiana, to 3168 inhabitants in Boundioba. All volunteers aged 18-65 years who presented for evaluation were included in the study.

\section{Study design}

A cross-sectional survey was performed from June 2014 in the three study villages to May 2015 to assess (i) the prevalence of the two major filarial infections and (ii) the prevalence of coincident delayed type hypersensitivity (DTH) responses to leishmanin as measured by skin test. The Fig. 2 shows the study participants distributions between the 2 study areas (North and South Sudan Savanna) and the different tests performed.

\section{Clinical assessment at inclusion}

All volunteers underwent a brief interview and an examination targeting the main signs and symptoms of the 


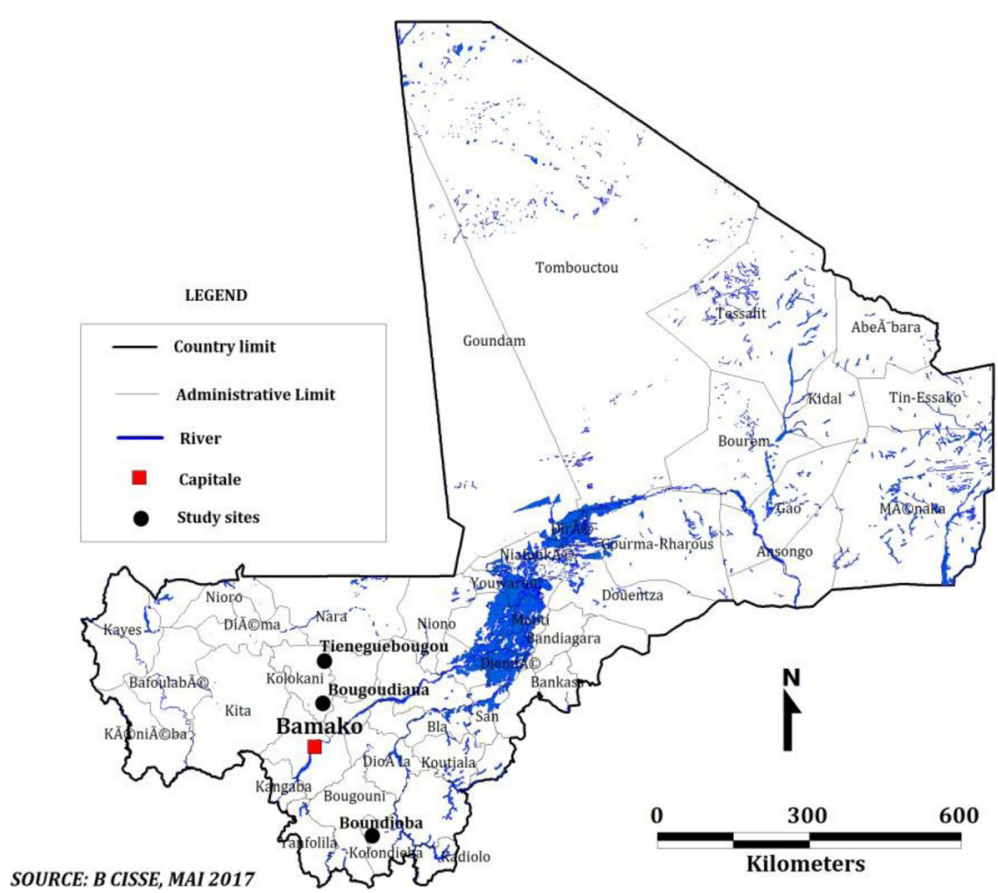

Fig. 1 Study sites location. The dots represent the study villages

two study diseases. For LF, hydrocele and elephantiasis were researched through the interview (hydrocele) and the examination (elephantiasis). Leishmaniasis-related wounds were checked through both the interview and the examination.

\section{Laboratory evaluations/assays}

Thick blood smear

Finger-prick and venous blood samples were collected using a calibrated thick blood smear $(60 \mu \mathrm{l})$, obtained during the daytime. The blood was drawn onto a microscope slide,

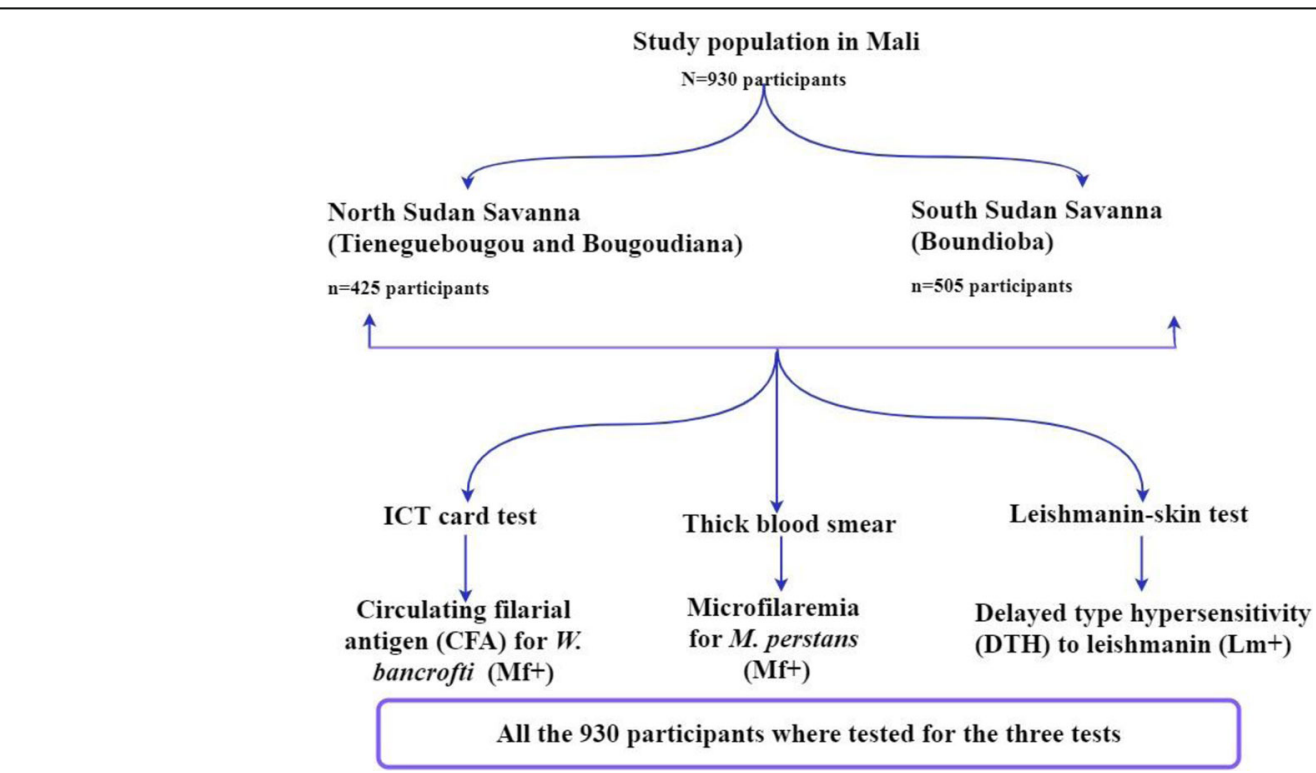

Fig. 2 Study design. Abbreviations: Mf+, ICT positive for Wuchereria bancrofti or thick blood smear positive for Mansonella perstans (= filarial infection); Lm+, LST positive for Leishmania major (= Leishmania infection) 
dried and stained with $10 \%$ Giemsa using standard procedures. The stained smears were examined using a light microscope with a $10 \times$ objective for the detection of $M$. perstans microfilariae (see Fig. 2).

\section{Immunochromatographic card test (ICT)}

The ICT Filariasis test used is a rapid-format filarial antigen test that was developed by ICT diagnostics (BinaxNow ${ }^{\circ}$ Filariasis test, Alere Inc., Scarborough, USA). The test is designed for detection of soluble $W$. bancrofti antigens that circulate in the blood of infected humans. The test was performed according to the manufacturer's instructions.

\section{Leishmanin skin test (LST)}

LST is an indication of previous exposure to Leishmania parasites. LST material is supplied as sterile aqueous $2.5 \mathrm{ml}$ suspensions, with each $\mathrm{ml}$ containing $6 \times 106$ killed $L$. major promastigotes (strain MRHO/IR/75/ER) in phosphate buffered saline and $0.01 \%$ thimerosal, $\mathrm{pH} 7.0-7.1$ (stable for 5 years when stored at $2-8{ }^{\circ} \mathrm{C}$ ). LST has a very good sensitivity and specificity varying from $80 \%$ to $100 \%$ [24]. The leishmanin $(0.1 \mathrm{ml})$ was injected intra-dermally in the left forearm. Readings were taken 48 to $72 \mathrm{~h}$ after the injection using a ball point pen to determine the size of the induration. Measurements with a diameter greater than $5 \mathrm{~mm}$ were considered positive [25].

\section{Data management and analysis}

Data were recorded on excel spreadsheet and statistical analysis was performed using GraphPad Prism version 7.03 (GraphPad Software Inc., San Diego, CA, USA). Statistically significant differences between proportions were analyzed using Pearson's chi-square test.

\section{Results}

\section{Characteristics of the study population in the two} ecologically distinct settings

A total of 930 study subjects (230 in Tieneguebougou, 195 in Bougoudiana, and 505 in Boundioba) of both genders aged 18 to 65 years old were included in the study. In each village, the number of female participants was higher with a female to male sex ratio of 1.6 in Tieneguebougou and Bougoudiana, and 3.5 in Boundioba. The median age in Tieneguebougou and Bougoudiana, and Boundioba was 35 (range 25-48) and 32 (range 22-44.5) years respectively.

\section{Prevalence of filarial and Leishmania parasite infections}

For filarial infections, we found a prevalence of $8.70 \%$ (81/ 930) for $M$. perstans infection and 8.00\% (74/930) for $W$. bancrofti infection. Furthermore, the prevalence for $M$. perstans and for W. bancrofti increased gradually with age (Table 1). The prevalence of $M$. perstans microfilaremia in Tieneguebougou and Bougoudiana, and Boundioba was 7.76\% (33/425) and 9.50\% (48/505), respectively (Fig. 3).
Table 1 Prevalence of M. perstans, W. bancrofti and L. major infections among the participants according to sex and age group

\begin{tabular}{|c|c|c|c|c|}
\hline & Total examined & M. perstans ${ }^{a}$ & W. bancrofti $i^{b}$ & L. major \\
\hline & $(N)$ & Positive $n(\%)$ & Positive $n(\%)$ & Positive $n(\%)$ \\
\hline \multicolumn{5}{|l|}{ Sex } \\
\hline Male & 274 & $27(9.9)$ & $20(7.3)$ & $28(10.2)$ \\
\hline Female & 656 & $54(8.2)$ & $54(8.2)$ & $44(6.7)$ \\
\hline \multicolumn{5}{|l|}{ Age group } \\
\hline $18-27$ & 325 & $24(7.4)$ & $17(5.2)$ & $12(3.7)$ \\
\hline $28-37$ & 238 & $16(6.7)$ & $21(8.8)$ & $18(7.6)$ \\
\hline $38-47$ & 165 & $15(9.1)$ & $17(10.3)$ & $15(9.1)$ \\
\hline $48-57$ & 125 & 17 (13.6) & $12(9.6)$ & 17 (13.6) \\
\hline$\geq 58$ & 77 & $9(11.7)$ & $7(9.1)$ & $10(13.0)$ \\
\hline Total & 930 & $81(8.7)$ & $74(8.0)$ & $72(7.7)$ \\
\hline
\end{tabular}

${ }^{a}$ Mansonella perstans (from microfilaremia prevalence)

${ }^{\mathrm{b}}$ Wuchereria bancrofti (from circulating filarial antigen prevalence)

'Leishmaniasis diagnosis was done using Delayed Type Hypersensitivity (DTH) to Leishmanin Skin Test (LST)

These prevalences were comparable between the two sites $\left(\chi^{2}=0.88, d f=1, P=0.35\right)$. However, the positivity rate of $W$. bancrofti circulating filarial antigen (CFA) detected by ICT was significantly higher in Boundioba, 10.30\% (52/ $505)$ as compared to Tieneguebougou and Bougoudiana, $5.20 \%(22 / 425)\left(\chi^{2}=8.26, d f=1, P=0.004\right)$ (Fig. 3).

The overall prevalence for Leishmania infection (indicated by positive LST) was $7.74 \%$ (72/930) with $10.21 \%$ $(28 / 274)$ in men and $6.70 \%(44 / 656)$ in women $\left(\chi^{2}=3.33\right.$, $d f=1, P=0.067$ ) (Table 1$)$. This prevalence gradually increased with age and was significantly higher in Tieneguebougou and Bougoudiana (15.05\%; 64/425) as compared to Boundioba, $(1.58 \% ; 8 / 505) \quad\left(\chi^{2}=8.26, d f=1, \quad P<0.0001\right)$ (Fig. 3). None of the study volunteers showed clinical signs or symptoms related to the study diseases.

\section{Prevalence of filarial and Leishmania co-infections}

The overall prevalence of concurrent infections $\left(\mathrm{Mf}^{+} / \mathrm{LST}\right.$ ${ }^{+}$) among individuals was $1.51 \%$ (14/930), with 6.24\% (58/ 930) $\mathrm{Mf}^{-} / \mathrm{LST}^{+}$and $13.76 \%$ (128/930) $\mathrm{Mf}^{+} / \mathrm{LST}^{-}$. Of the 14 cases of co-infection, 12 of 425 subjects (2.82\%) were from Tieneguebougou and Bougoudiana, and 2 of 505 subjects $(0.40 \%)$ were from Boundioba. There were more co-infections in men than women (ratio of $8 / 6$ ).

\section{Discussion}

In this study, we show that $W$. bancrofti infection prevalences were $7.69 \%$ in Tieneguebougou, 3.04\% in Bougoudina, and $10.30 \%$ in Boundioba (Fig. 3) suggesting that bancroftian filariasis is still a public health problem in these regions of Mali. The prevalences of microfilaremia for $M$. perstans were $11.79 \%, 4.35 \%$ and $9.50 \%$, for Tieneguebougou, Bougoudiana and Boundioba, respectively, suggesting that this parasite is currently the most 


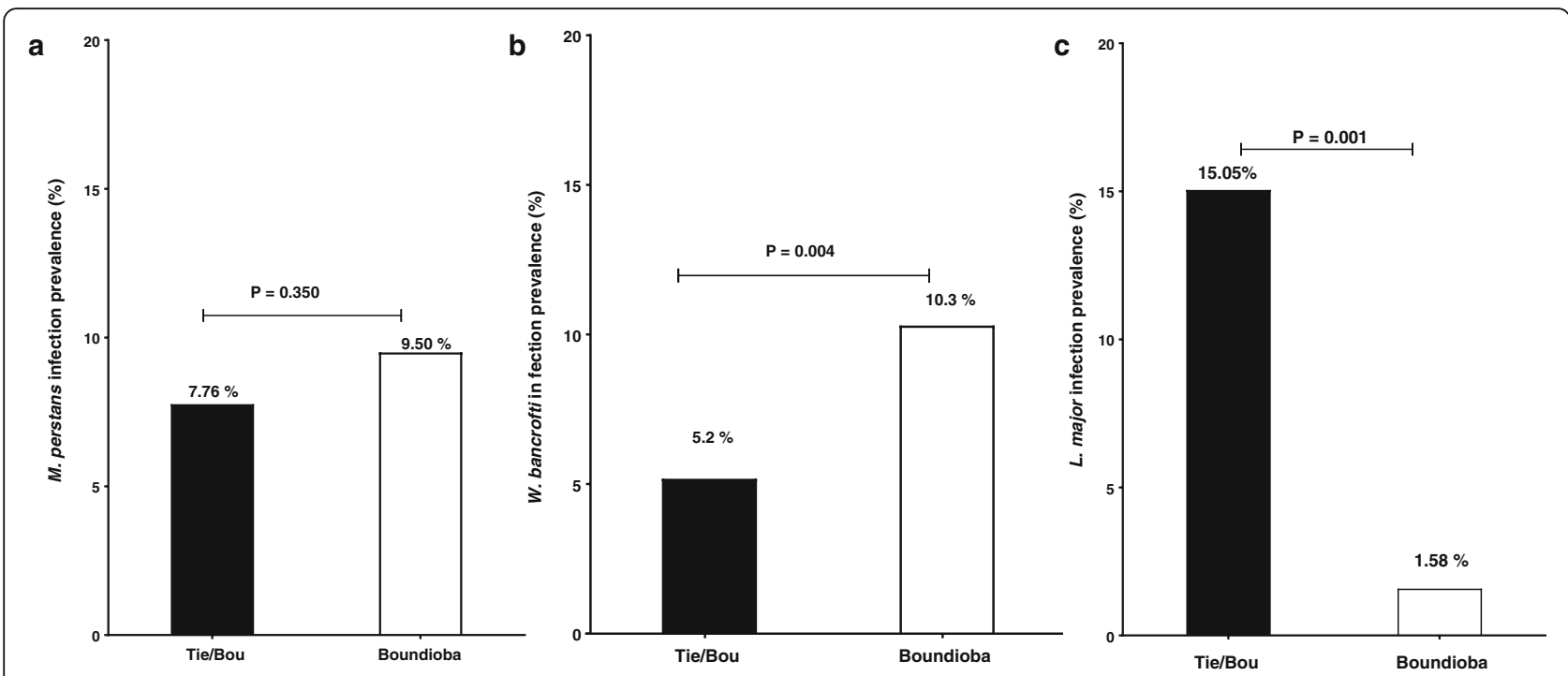

Fig. 3 Prevalence of M. perstans (a) W. bancrofti (b) and L. major (c) infections among study populations in Tieneguebougou and Bougoudiana, and Boundioba. Abbreviation: Tie/Bou, Tieneguebougou and Bougoudiana

prevalent filarial infection in Mali. This study further confirms that $M$. perstans is widespread througout the country and supports previous studies done in this region [26]. Further studies need to be performed to evaluate the clinical significance of mansonellosis in humans. Together, these results suggest that filarial infections as well as Leishmania infections are still endemic in Kolokani (Tieneguebougou and Bougoudiana) and Kolondieba (Boundioba) districts of Mali.

Within the 142 infected volunteers with at least one of the two filarial infections (W. bancrofti and M. perstans), a co-infection prevalence of $9.15 \%$ (13/142) was observed. This observation indicates the endemicity of both filarial infections in the study areas. This co-infection was also observed in a neighboring area of Kolokani before any mass drug administration with a high prevalence of $48.3 \%$ (69/ 143) [23]. A high prevalence of $M$. perstans infection was also reported in other countries such as Senegal [27], Nigeria [28], Ghana [29], Burkina Faso [30], Gabon [31], as well as Cameroon in Central Africa [32]. Moreover, previous studies reported symptoms such as symptomatic hypereosinophilia related to $M$. perstans microfilaremia [33].

While several mass drug administration campaigns have been implemented since 2005 in Mali, the current study suggests that filarial infections persist regardless of previous implementations. Furthermore, despite a drastic decrease [34] due to nine annual MDA rounds in the study area, LF prevalence is still higher than the $1 \%$ endemicity threshold. These findings are important not only to the health authorities involved in filariasis elimination programme's efficacy assessments, but also to the scientific community for providing useful information to achieve elimination by 2020 [35].
Another interesting finding in our study was the higher positivity rate of LST in Kolokani (Tieneguebougou and Bougoudiana) compared to Kolondieba (Boundioba) $(P<0.0001)$ (Fig. 3). Our previous data indicate that sand fly anti-saliva antibody levels are similar across these two areas [36]. The differences may be due to a higher infection rate of sand flies in Kolokani area that is contiguous to two villages in Central Mali. In these areas, CL has an estimated infection rate of $2.7 \%$ in the female population of P. duboscqi [21]. The difference in infection rates between the two areas could be further explained by the distribution of reservoir mammals, climate, immunity, or even genetic background [37].

Epidemiological studies suggest that $\mathrm{CL}$ is widely distributed throughout Mali [38]. In fact, the prevalence of $L$. major infection is as high as $45 \%$ within individuals residing in central Mali (Kemena, 45\% LST-positive and Sougoula 20\% LST-positive) [22]. Furthermore, our study indicates that $1.5 \%$ of the total population in the two study districts (Kolokani and Kolondieba) are co-infected with Leishmania and filariae $\left(\mathrm{Mf}^{+} / \mathrm{Lm}^{+}\right)$(Fig. 4) suggesting the occurrence of poly-parasitism in these regions. To our knowledge this is the first study reporting a prevalence rate of filarial/Leishmania (L. major and W. bancrofti and/or M. perstans) coinfection in Mali. A co-infection of filariasis and visceral leishmaniasis (W. bancrofti and L. donovani) has been also reported in a resident of Bihar, India [39]. Other studies have established co-infections with poly-parasitism (malaria and filariae) in Mali $[5,40]$, as well as other parts of Africa (loiasis and onchocerciasis in Nigeria, and schistosomiasis and hookworm infection in Kenya) [41, 42].

Finally, co-infection may severely impact the immune response. How chronic filarial infections alter the host's 


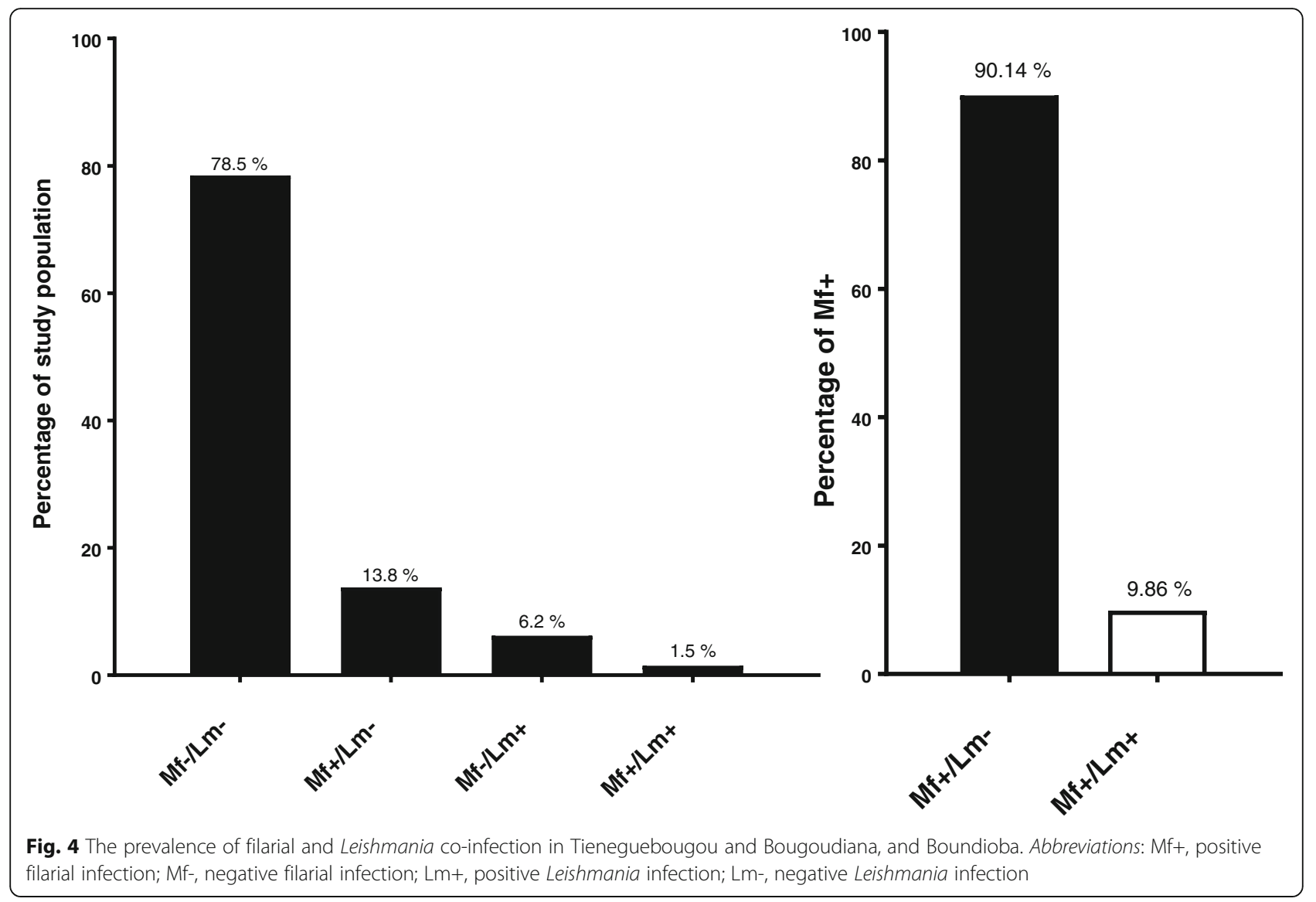

immune response to Leishmania [43], to further facilitate $L$. major infection in Mali, is currently under investigation.

\section{Conclusions}

Filarial and Leishmania infections are still endemic in Kolokani (Tieneguebougou and Bougoudiana) and Kolondieba (Boundioba) districts of Mali suggesting the co-endemicity of these two diseases. Since both infections are vector borne diseases with mosquitoes and sand flies as respective vectors, an integrated vector control approach should be considered in co-endemic areas. While currently there are no leishmaniasis control programmes in Mali, filarial and Leishmania co-infection might be of great importance to the neglected tropical diseases control programme. More studies need to be undertaken to assess the effect of co-infection on the host immune response that may influence the outcome of disease.

\section{Abbreviations}

CFA: Circulating filarial antigen; CL: Cutaneous leishmaniasis; DTH: Delayed type hypersensitivity; ICT: Immunochromatographic test; LF: Lymphatic filariasis; LST: Leishmanin skin test; MDA: Mass drug administration; NTDs: Neglected tropical diseases
Acknowledgements

The authors would like to thank the study villages, the local health care staff of Kolokani and Kolondieba for their cooperation and facilitation of the field studies. The authors would also like to thank the CNAM team for their collaboration.

\section{Funding}

Research reported in this publication was supported by the National Institute of Allergy and Infectious Diseases of the National Institutes of Health under Award Number P50AI098505 (Tropical Medicine Research Center, TMRC). The content is solely the responsibility of the authors and does not necessarily represent the official views of the funders. The funders had no role in the study design, data collection and analysis, decision to publish, or preparation of the manuscript.

\section{Availability of data and materials}

The data supporting the conclusions of this article are included within the article. Additional information is available from the authors upon reasonable request.

\section{Authors' contributions}

MBS, YIC, RTS, TBN, SK, FO, JGV, OF, SD and SFT conceived and designed the study. MBS YIC, FO, RTS, TBN, OF, SYC, BT, SD, MEC, SS and IMS performed the experiments and collected the data. MBS, YIC, SYC, ID, RTS, FO, SD and SFT analyzed the data. TBN, RTS, FO, SD and SFT contributed reagents, materials, analysis tools. MBS, RTS, YIC, SYC, TBN, SD and FO managed the data and drafted the paper, did the statistical analysis and helped to draft the manuscript. All authors read and approved the final manuscript.

Ethics approval and consent to participate

The Institutional Review Board of the National Institutes of Health, USA and the Ethical Committee of the Faculty of Medicine, Pharmacy and OdontoStomatology of the University of Bamako, Mali approved the study (Protocol \# 12-0075). The study was explained to all participants in Bambara, the local 
language, or in French. Written informed consent was obtained from all the volunteers prior to their participation in the study.

\section{Consent for publication}

Not applicable.

\section{Competing interests}

The authors declare that they have no competing interests.

\section{Publisher's Note}

Springer Nature remains neutral with regard to jurisdictional claims in published maps and institutional affiliations.

\section{Author details}

${ }^{1}$ International Center of Excellence in Research, Faculty of Medicine and Odontostomatology, Point G, Bamako, Mali. ${ }^{2}$ National Institutes of Health, Bethesda, MD 20892, USA. ${ }^{3}$ National Institutes of Health, Rockville, MD 20852, USA. ${ }^{4}$ Centre National d'Appui à la lutte contre la Maladie (CNAM), Bamako, Mali.

Received: 3 March 2017 Accepted: 12 November 2017 Published online: 08 January 2018

\section{References}

1. Hotez PJ, Kamath A. Neglected tropical diseases in sub-saharan Africa: review of their prevalence, distribution, and disease burden. PLoS Negl Trop Dis. 2009:3(8):e412.

2. Pani S, Kumaraswami V, Das L. Epidemiology of lymphatic filariasis with special reference to urogenital-manifestations. Indian J Urol. 2005;21(1):44.

3. Global programme to eliminate lymphatic filariasis. Relevé épidémiologique hebdomadaire. Programme mondial pour l'élimination de la filariose lymphatique: rapport de situation, 2014. OMS. Relevé épidémiologique Hebd. 2015;38(90):489-504

4. Hotez PJ, Bottazzi ME, Strych U, Chang LY, Lim YA, Goodenow MM AbuBakar S. Neglected tropical diseases among the Association of Southeast Asian Nations (ASEAN): overview and update. PLoS Negl Trop Dis. 2015;9(4):e0003575.

5. Metenou S, Dembélé B, Konate S, Dolo H, Coulibaly SY, Coulibaly Yl, et al. Patent filarial infection modulates malaria-specific type 1 cytokine responses in an IL-10-dependent manner in a filaria/malaria-coinfected population. J Immunol. 2009;183(2):916-24.

6. Dembélé $M$, Bamani $S$, Dembélé $R$, Traoré $M O$, Goita $S$, Traoré $M N$, et al. Implementing preventive chemotherapy through an integrated national neglected tropical disease control program in Mali. PLoS Negl Trop Dis. 2012;6(3)

7. Coulibaly YI, Dembele B, Diallo AA, Kristensen S, Konate S, Dolo H, et al. Wuchereria bancrofti transmission pattern in southern Mali prior to and following the institution of mass drug administration. Parasit Vectors. 2013; 6(1):247.

8. World Health Organization. Control of the leishmaniases. World Health Organ Tech Rep Ser. 2010;978(949):22-6.

9. Alvar J, Vélez ID, Bern C, Herrero M, Desjeux P, Cano J, et al. Leishmaniasis worldwide and global estimates of its incidence. PLoS One. 2012;7(5): e35671.

10. Aoun K, Bouratbine A. Cutaneous leishmaniasis in North Africa: a review. Parasite. 2014:21:14.

11. Sabbatani S, Isuierdo Calzado A, Ferro A, Lopez Goudiaby AM, Borghi V, Zanchetta GP, et al. Atypical leishmaniasis in an HIV-2-seropositive patient from Guinea-Bissau. AIDS. 1991;5(7):899-901.

12. Larivière M. Cutaneous leishmaniasis in Senegal: clinical and epidemiological aspects. Bull Soc Med Afr Noire. 1966;11(1):119-33.

13. Ranque P. Leishmaniasis in Senegal. Med Trop. 1978;38(4):413-7.

14. Develoux M, Blanc L, Garba S, Mamoudou HD, Warter A, Ravisse P. Cutaneous leishmaniasis in Niger. Am J Trop Med Hyg. 1990;43(1):29-30.

15. Monjour L, de Lorenzi G, Volta C, Vouldoukis I, Frommel D. Leishmaniasis in Burkina Faso. Trans R Soc Trop Med Hyg. 1987;81(5):746.

16. Imperato PJ, Diakité S. Leishmaniasis in the Republic of Mali. Trans R Soc Trop Med Hyg. 1969;63(2):236-41.

17. Paz C, Doumbia S, Keita S, Sethi A. Cutaneous leishmaniasis in Mali. Dermatol Clin. 2011;29(1):75-8.

18. Fryauff DJ, Hanafi HA, Klena JD, Hoel DF, Appawu M, Rogers W, et al. Short report: ITS-1 DNA sequence confirmation of Leishmania major as a cause of cutaneous leishmaniasis from an outbreak focus in the Ho District, southeastern Ghana. Am J Trop Med Hyg. 2006;75(3):502-4.

19. Villinski JT, Klena JD, Abbassy M, Hoel DF, Puplampu N, Mechta S, et al. Evidence for a new species of Leishmania associated with a focal disease outbreak in Ghana. Diagn Microbiol Infect Dis. 2008;60(3):323-7.

20. Paz C, Samake S, Anderson JM, Faye O, Traore P, Tall K, et al. Short report: Leishmania major, the predominant Leishmania species responsible for cutaneous leishmaniasis in Mali. Am J Trop Med Hyg. 2013;88(3):583-5.

21. Anderson JM, Samake $S$, Jaramillo-Gutierrez G, Sissoko I, Coulibaly CA, Traoré $B$, et al. Seasonality and prevalence of Leishmania major infection in Phlebotomus duboscai neveu-lemaire from two neighboring villages in Central Mali. PLoS Negl Trop Dis. 2011;5(5):e1139.

22. Oliveira F, Doumbia S, Anderson JM, Faye O, Diarra SS, Traoré $P$, et al. Discrepant prevalence and incidence of Leishmania infection between two neighboring villages in Central Mali based on leishmanin skin test surveys. PLoS Negl Trop Dis. 2009;3(12):e565.

23. Keiser PB, Coulibaly Yl, Keita F, Traore D, Diallo A, Diallo DA, et al. Clinica characteristics of post-treatment reactions to ivermectin/albendazole for Wuchereria bancrofti in a region co-endemic for Mansonella perstans. Am J Trop Med Hyg. 2003;69(3):331-5.

24. Imperato PJ, Fofana B, Sow O, Diallo S. Leishmanin skin sensitivity in the inland delta of the Niger. Trop Geogr Med. 1974;26(3):303-6.

25. Pineda JA, Macías J, Morillas F, Fernández-Ochoa J, Cara J, de la Rosa R, et al. False-positive results of leishmanin skin test due to phenol-containing diluent. Trans R Soc Trop Med Hyg. 2001;95(2):173-4.

26. Keiser PB, Coulibaly Y, Kubofcik J, Diallo AA, Klion AD, Traoré SF, et al. Molecular identification of Wolbachia from the filarial nematode Mansonella perstans. Mol Biochem Parasitol. 2008;160(2):123-8.

27. Bassene H, Sambou M, Fenollar F, Clarke S, Djiba S, Mourembou G, et al. High prevalence of Mansonella perstans filariasis in rural Senegal. Am J Trop Med Hyg. 2015;93(3):601-6.

28. Akpan SS, Mbah M, Achi E. The occurrence of Mansonella perstans among residents of Calabar metropolis in Cross River state of Nigeria. Ann Parasitol. 2015:61(1):17-20.

29. Phillips RO, Frimpong M, Sarfo FS, Kretschmer B, Beissner M, Debrah A, et al Infection with Mansonella perstans nematodes in buruli ulcer patients, Ghana. Emerg Infect Dis. 2014;20(6):1000-3.

30. Bamba S, Barro-Traoré F, Liance M, Da O, Sanou C, Guiguemdé TR. Mansonelliasis identified by a cervicovaginal smear at the university hospital center of Bobo-Dioulasso (Burkina Faso). Med Sante Trop. 2012;22(4):444-6.

31. Bouyou Akotet MK, Owono-Medang M, Mawili-Mboumba DP, MoussavouBoussougou MN, Nzenze Afène S, Kendjo E, et al. The relationship between microfilaraemic and amicrofilaraemic loiasis involving co-infection with Mansonella perstans and clinical symptoms in an exposed population from Gabon. J Helminthol. 2015:90(4):1-7.

32. Wanji S, Amvongo-Adjia N, Koudou B, Njouendou AJ, Chounna Ndongmo PW, Kengne-Ouafo JA, et al. Cross-reactivity of filariasis ICT cards in areas of contrasting endemicity of Loa loa and Mansonella perstans in Cameroon: implications for shrinking of the lymphatic filariasis map in the central African region. PLoS Negl Trop Dis. 2015;9(11):e0004184.

33. Simonsen PE, Onapa AW, Asio SM. Mansonella perstans filariasis in Africa. Acta Trop. 2011;120(SUPPL. 1):S109-20.

34. Coulibaly $\mathrm{Yl}$, Dembele B, Diallo AA, et al. The impact of six annual rounds of mass drug administration on Wuchereria bancrofti infections in humans and in mosquitoes in Mali. Am J Trop Med Hygiene. 2015; 93(2):356-60.

35. World Health Organization. Resolution WHA 50.29: Elimination of lymphatic filariasis as a public health problem. Fiftieth World Heal Assem. 1997;(3):27-8.

36. Traoré B, Oliveira F, Faye O, Dicko A, Coulibaly CA, Sissoko IM, et al. Prevalence of cutaneous leishmaniasis in districts of high and low endemicity in Mali. PLoS Negl Trop Dis. 2016;10(11):e0005141.

37. Akhoundi M, Kuhls K, Cannet A, Votýpka J, Marty P, Delaunay P, et al. A historical overview of the classification, evolution, and dispersion of Leishmania parasites and sandflies. PLoS Negl Trop Dis. 2016:10(6):e0004770.

38. Kone AK, Delaunay P, Djimdé AA, Thera MA, Giudice PD, Coulibaly D, et al. Epidemiology of cutaneous leishmaniasis in five villages of Dogon country, Mali. Bull Soc Pathol Exot. 2012;105(1):8-15.

39. Ahmed $\mathrm{NH}$, Shwetha J, Samantaray JC, Jana KA. Case of mixed infection with filariasis and visceral leishmaniasis. Trop Parasitol. 2014;4(1):62-4.

40. Dolo H, Coulibaly YI, Dembele B, Konate S, Coulibaly SY, Doumbia SS, et al. Filariasis attenuates anemia and proinflammatory responses associated with 
clinical malaria: a matched prospective study in children and young adults. PLoS Negl Trop Dis. 2012;6(11):e1890.

41. Ojurongbe O, Akindele AA, Adeleke MA, Oyedeji MO, Adedokun SA, Ojo JF, et al. Co-endemicity of loiasis and onchocerciasis in rain forest communities in southwestern Nigeria. PLoS Negl Trop Dis. 2015;9(3):e0003633.

42. Bisanzio D, Mutuku F, Bustinduy AL, Mungai PL, Muchiri EM, King CH, Kitron U. Cross-sectional study of the burden of vector-borne and soil-transmitted polyparasitism in rural communities of Coast Province, Kenya. PLoS Negl Trop Dis. 2014;8(7):e2992.

43. O'Neal SE, Guimarães LH, Machado PR, Alcântara L, Morgan DJ, Passos S, et al. Influence of helminth infections on the clinical course of and immune response to Leishmania braziliensis cutaneous leishmaniasis. J Infect Dis. 2007;195(1):142-8

Submit your next manuscript to BioMed Central and we will help you at every step:

- We accept pre-submission inquiries

- Our selector tool helps you to find the most relevant journal

- We provide round the clock customer support

- Convenient online submission

- Thorough peer review

- Inclusion in PubMed and all major indexing services

- Maximum visibility for your research

Submit your manuscript at www.biomedcentral.com/submit
Biomed Central 